\title{
R. Finkeldey • G. Mátyás \\ Genetic variation of oaks (Quercus spp.) in Switzerland. 3. Lack of impact of postglacial recolonization history on nuclear gene loci
}

Received: 20 August 2001 / Accepted: 13 May 2002 / Published online: 6 July 2002

(C) Springer-Verlag 2002

\begin{abstract}
Quercus petraea, Quercus pubescens and Quercus robur are closely related and interfertile white oaks native to Switzerland. The three species are known to share identical cpDNA haplotypes, which are indicative of the postglacial recolonization history of populations. Only two haplotypes are common in Switzerland. We compared variation of cpDNA and of isozymes in 28 oak populations from Switzerland in order to assess the impact of the postglacial population history on current genetic structures of nuclear controlled isozyme gene loci. Species delineation was based on Principal Component Analysis of leaf morphological traits. The species status of populations was reflected at isozyme gene loci, but differentiation between populations with different cpDNA haplotypes and hence different recolonization history was very low at enzyme gene loci for all species. Thus, glacial and postglacial population history was not reflected at nuclear gene loci on the temporal and spatial scale covered by the present study. Extensive gene flow through pollen among populations is likely to have blurred a previously existing genetic differentiation at biparentally inherited gene loci that possibly evolved in the different glacial refugia of the above mentioned cpDNA haplotypes.
\end{abstract}

Keywords cpDNA haplotype - Isozymes · Population history $\cdot$ Quercus spp.

Communicated by D.B. Neale

R. Finkeldey $(\bullet) \cdot$ G. Mátyás

Swiss Federal Research Institute WSL, Zürcherstrasse 111, CH-8903 Birmensdorf, Switzerland

e-mail: rfinkel@gwdg.de

Tel.: +49-551-393536, Fax: +49-551-398367

Present address:

R. Finkeldey, Institute of Forest Genetics and Forest Tree Breeding, Göttingen University, Büsgenweg 2, D-37077 Göttingen, Germany

Present address:

G. Mátyás, University Children’s Hospital,

University of Zurich,

Division of Metabolism and Molecular Pediatrics,

Steinwiesstrasse 75, CH-8032 Zürich, Switzerland

\section{Introduction}

Population isolation and gene flow are two counteracting forces shaping patterns of genetic differentiation among populations. Many European animal and plant species survived the Quaternary cold periods in isolated refugia in the South of the continent. Populations were likely to become genetically differentiated from each other during the long phases of spatial isolation (Hewitt 2000). Previously isolated populations came into contact during recolonization of Central and Northern Europe after the end of the last glaciation. The extent of gene flow among populations from different refugia is a crucial factor for today's distribution of genetic information.

Pollen and seeds are the main vehicles for the movement of genetic information in plants. Genetic information of chloroplasts (cpDNA) is maternally inherited in most angiosperms including oaks (Reboud and Zeyl 1994; Dumolin et al. 1995). Accordingly, variation patterns of cpDNA reflect only gene flow through seeds. Maternally inherited markers are useful tools to elucidate the migration history of plants (McCauley 1995). However, variation patterns at biparentally inherited nuclear gene loci can strongly differ from those found at maternally inherited chloroplast loci.

Oaks (Quercus spp.) are anemogamous, barochorous or exozoochorous trees dominating many forest types in the northern hemisphere. Quercus petraea, Quercus pubescens and Quercus robur are closely related, interfertile oak species of the section Lepidobalanus ("white oaks") with a wide distribution in Europe (Aas 1998). They are the most-frequent oaks native to Switzerland, occurring in pure or mixed forests up to an altitude of $1,400 \mathrm{~m}$ a.s.l. throughout the country (Brändli 1996).

Oaks survived the last ice age in refugia in the South of Europe. Pollen analysis provides evidence for separate refugia in Spain, Italy and the Balkan peninsular (Huntley and Birks 1983). Oaks reached the South of what is today Switzerland approximately 11,000 years ago. Areas north of the Alps were recolonized between 9,000 and 8,000 years before the present (Burga and Perret 1998). Pollen 
analytical data provide no information on refugial regions or detailed recolonization routes of oaks in Switzerland.

CpDNA variation proved to be a reliable tool for the analysis of the postglacial recolonization history of oaks in Europe (Ferris et al. 1993; Dumolin-Lapègue et al. 1997). Forty five cpDNA haplotypes of "white oaks" in Europe have been identified by means of PCR-RFLP using four primer-enzyme combinations (Petit et al. 2002). However, only two types, "haplotype 1" and "haplotype 7" (nomenclature as described by Dumolin-Lapègue et al. 1997 and Petit et al. 2002), are common in Switzerland (Mátyás and Sperisen 2001). The European distribution of "haplotype 1" (the "western" haplotype according to Ferris et al. 1993) strongly suggests glacial refugia of this type in Italy, while refugia of "haplotype 7" (the "eastern" haplotype according to Ferris et al. 1993) possibly were on the Balkan Peninsula (DumolinLapègue et al. 1997; Petit et al. 2002).

We compared patterns of genetic variation at maternally inherited cpDNA (Mátyás and Sperisen 2001) and biparentally inherited isozyme gene markers (Finkeldey 2001a) in oak (Quercus spp.) populations from Switzerland in order to test whether or not the recolonization history of oaks as mirrored by patterns of cpDNA variation has an impact on today's distribution of genetic information at nuclear gene loci. Such an impact of the glacial and postglacial history of populations is expected to be manifested by an association between variation patterns at maternally and biparentally inherited genes.

\section{Materials and methods}

Plant material

Material was sampled in 28 oak populations throughout Switzerland (Fig. 1, Table 1). In each population twigs with dormant buds were collected from 100 randomly selected adult trees with a minimum distance of $30 \mathrm{~m}$, and frozen at $-80{ }^{\circ} \mathrm{C}$. Only 83 and 56 trees were sampled in the populations "Mt. Caslano" and "Novaggio", respectively. One hundred leaves were randomly collected from the ground in the same area where trees were sampled. The leaves were dried and kept in a herbarium located at the Swiss Federal Research Institute WSL, Birmensdorf.

Species identification

Species identification of populations was based on population mean values for seven leaf morphological traits: lamina length, petiole length, lobe width, sinus width, number of intercalary veins, basal shape of the lamina and abaxial lamina pubescence. These traits proved to be suitable for the discrimination of European oak species in previous studies (Dupouey and Badeau 1993; Bacilieri et al. 1996). Populations were grouped by means of Principal Component Analysis (PCA; Backhaus et al. 2000) and assigned to species based on their first and second factor scores (for details of the analysis of leaf morphological traits for the purpose of species identification see Finkeldey 2001a, b).

\section{Identification of cpDNA haplotypes}

At least five trees per population were investigated for their cpDNA haplotypes ("western" or "eastern" according to Ferris et al. 1993). Data were either taken from Mátyás (1999; 13 populations), or extraction of DNA and PCR-RFLP of the tRNA ${ }^{\text {Leul } 1 \text { in- }}$

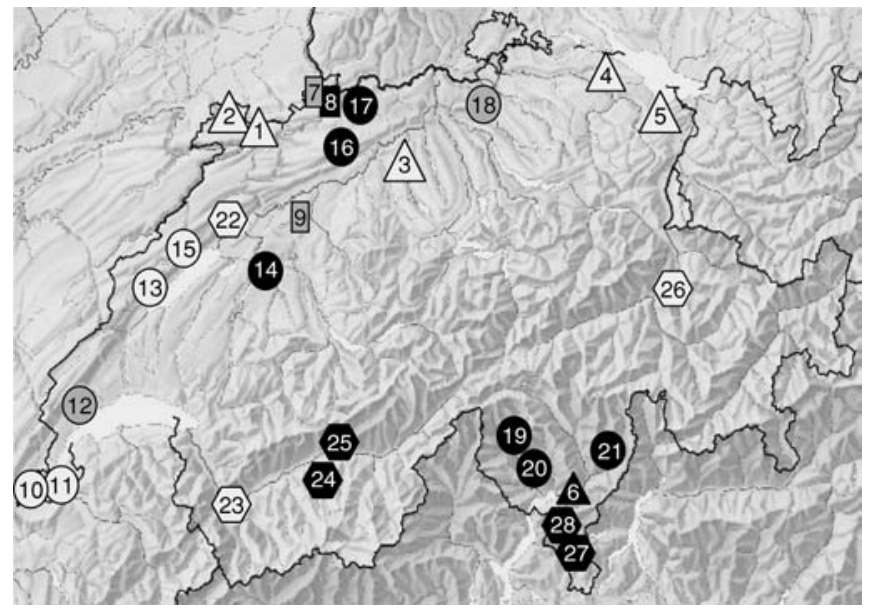

Fig. 1 Location of the investigated Quercus populations in Switzerland. Numbers as in Table 1; shading according to haplotype [white: populations with only a "eastern" haplotype according to Ferris et al. (1993); black: populations with only a "western" haplotype according to Ferris et al. (1993); grey: populations with both haplotypes]; symbols according to dominating species (triangle: $Q$. robur; circle: $Q$. petraea; rectangle: mixed $Q$. roburlQ. petraea; hexagon: $Q$. pubescens)

tron was performed according to Ferris et al. (1993) and Mátyás and Sperisen (2001; 15 populations).

\section{Isozyme electrophoresis}

Enzyme extraction, electrophoresis in starch gels, and staining followed standard procedures (Müller-Starck et al. 1996; Zanetto et al. 1996) with slight modifications (Finkeldey 2001a, b). The following 14 enzyme systems coding for 17 polymorphic gene loci were investigated (in brackets: E.C.-No. and investigated gene loci): alanine-aminopeptidase (3.4.11.1; $A A P-A)$; aconitase (4.2.1.3; $A C O-A)$; acid phosphatase $(3.1 .3 .2 ; A C P-C)$; alcohol-dehydrogenase $(1.1 .1 .1 ; A D H-A)$; glutamate-dehydrogenase $(1.4 .1 .3 ; G D H-A)$; glutamate-oxaloacetate-transaminase $(2.6 .1 .1$; GOT-B); isocitratedehydrogenase $(1.1 .1 .42 ; I D H-A, I D H-B)$; malate-dehydrogenase (1.1.1.37; $M D H-A)$; menadione-reductase (1.6.99.2; $M N R-A)$; NADH-dehydrogenase $(1.6 .99 .3 ; N D H-A) ; 6$-phosphogluconatedehydrogenase (1.1.1.44; 6-PGDH-A, 6-PGDH-B); phosphoglucose-isomerase (5.3.1.9; PGI-A, PGI-B); phosphoglucomutase (2.7.5.1; $P G M-A)$; and shikimic-acid-dehydrogenase (1.1.1.25; $S K D H-A)$.

\section{Data analysis}

Data analysis was based on allelic frequency distributions at the above 17 polymorphic isozyme loci. The impacts of the cpDNA haplotype and of the species status of populations on allele frequencies were tested for statistical significance by means of a twoway analysis of variance (ANOVA) without replication (Sokal and Rohlf 1995).

Genetic variation within populations was quantified as the expected heterozygosity $\left(\mathrm{H}_{\mathrm{e}}\right.$; Berg and Hamrick 1997). Populations were grouped according to their species status and their cpDNA haplotypes, respectively, and group means of $\mathrm{H}_{\mathrm{e}}$ were computed. The significance of differences among group means was tested by a single-classification ANOVA with unequal sample sizes (Sokal and Rohlf 1995) taking into account all groups and all possible pairs of groups, respectively.

A hierarchical partitioning of the total genetic variation $\left(\mathrm{H}_{\mathrm{T}}\right)$ was performed according to Nei (1973). The following hierarchy 
Table 1 Dominating species based on leaf morphological traits, cpDNA haplotype, and expected heterozygosity $\left(\mathrm{H}_{\mathrm{e}}\right)$ at 17 isozyme gene loci for 28 Quercus populations from Switzerland

\begin{tabular}{|c|c|c|c|c|}
\hline No. & Population & Species & cpDNA & $\mathrm{H}_{\mathrm{e}}$ \\
\hline 1 & Bonfol & Q. robur & Eastern & 0.229 \\
\hline 2 & Lugnez & Q. robur & Eastern & 0.251 \\
\hline 3 & Wölfinswil & Q. robur & Eastern & 0.256 \\
\hline 4 & Tägerwilen & Q. robur & Eastern & 0.235 \\
\hline 5 & Uttwil & Q. robur & Eastern & 0.233 \\
\hline 6 & Magadino & Q. robur & Western & 0.239 \\
\hline 7 & Allschwil & Mixed $Q$. rob./Q. pet. & Western/eastern & 0.251 \\
\hline 8 & Muttenz & Mixed $Q$. rob./Q. pet. & Western & 0.259 \\
\hline 9 & Büren & Mixed $Q$. rob./Q. pet. & Western/eastern & 0.257 \\
\hline 10 & Satigny & Q. petraea & Eastern & 0.246 \\
\hline 11 & Jussy & Q. petraea & Eastern & 0.249 \\
\hline 12 & Alaman & Q. petraea & Western/eastern & 0.262 \\
\hline 13 & Corcelles & Q. petraea & Eastern & 0.246 \\
\hline 14 & Galm & Q. petraea & Western & 0.247 \\
\hline 15 & Bois de devant & Q. petraea & Eastern & 0.247 \\
\hline 16 & Schoren & Q. petraea & Western & 0.260 \\
\hline 17 & Magden & Q. petraea & Western & 0.261 \\
\hline 18 & Bülach & Q. petraea & Western/eastern & 0.254 \\
\hline 19 & Cavergno & $Q$. petraea & Western & 0.234 \\
\hline 20 & Gordevio & Q. petraea & Western & 0.235 \\
\hline 21 & Castaneda & $Q$. petraea & Western & 0.241 \\
\hline 22 & Le Landeron & Q. pubescens & Eastern & 0.239 \\
\hline 23 & Fully & Q. pubescens & Eastern & 0.194 \\
\hline 24 & St. Luc & Q. pubescens & Western & 0.213 \\
\hline 25 & Gampel & Q. pubescens & Western & 0.180 \\
\hline 26 & Tamins & Q. pubescens & Eastern & 0.240 \\
\hline 27 & Mt. Caslano & Q. pubescens & Western & 0.203 \\
\hline 28 & Novaggio & Q. pubescens & Western & 0.236 \\
\hline
\end{tabular}

levels were chosen: variation among species; variation among cpDNA haplotypes within species; variation among populations within cpDNA haplotypes and species; and variation within populations. The proportion of genetic diversity due to differentiation among populations $\left(\mathrm{F}_{\mathrm{ST}}=\mathrm{G}_{\mathrm{ST}}\right.$; Nei 1973) was also separately computed for each species.

Average genetic distances $\mathrm{d}_{0}$ (Gregorius 1984; equivalent to the genetic distance according to Prevosti et al. 1975) within and between groups of populations with identical species status and with identical cpDNA haplotype, respectively, were computed, and the significance of differences between pairwise average genetic distances was tested by a single-classification ANOVA (Sokal and Rohlf 1995).

Populations with mixtures of different species or haplotypes were excluded from the two-way ANOVA of allele frequencies, the partitioning of genetic variation, and the computation of average genetic distances.

Patterns of genetic differentiation among populations at isozyme gene loci were illustrated by a cluster diagram using UPGMA (Sneath and Sokal 1973) based on genetic distances $\mathrm{d}_{0}$ (Gregorius 1984).

The computer programs BIOSYS-2 (Swofford and Selander 1981), GSED (Gillet 1994) and WINSTAT (Braeunig and Fitch 1998) were used for data analysis.

\section{Results}

Identification of species and haplotypes

Principal component analysis of leaf morphological traits allowed us to group the investigated populations into populations dominated by the robur, petraea and pubescens leaf type, respectively, and into intermediate populations (Fig. 2, Table 1). However, while populations of the robur type were clearly differentiated from the other types, no unambiguous distinction was possible between populations of the pubescens type and the petraea type.

Twelve populations show only the "western" cpDNA haplotype according to Ferris et al. (1993). Another 12 populations had only the "eastern" haplotype. Both haplotypes co-occurred in four populations (Table 1). Populations with either only the "eastern" or only the "western" haplotype were observed in all investigated species.

Genetic diversity and differentiation at isozyme gene loci

All populations revealed high genetic variation at isozyme gene loci (Table 1). The average expected heterozygosity was slightly, but significantly $(P<0.05)$, lower for $Q$. pubescens populations as compared to $Q$. robur, $Q$. petraea, and intermediate populations (Table 2). The average levels of genetic variation for populations with the "western" and the "eastern" haplotype, respectively, were not significantly different from each other (Table 2). Single-classification ANOVA revealed an impact of the species status on $\mathrm{H}_{\mathrm{e}}(P<0.001)$, but no statistically significant impact on the cpDNA haplotype.

Twenty three populations were dominated by a single species and a single haplotype (Table 1). The cpDNA haplotype had a significant impact on the allele frequencies of these populations for only one out of 75 alleles from 17 gene loci at the 5\% level of significance (IDH$\mathrm{A}_{2}$ ), and for another allele at the 1\% level (MNR-A $)_{3}$. This result can be expected by chance alone. A signifi- 


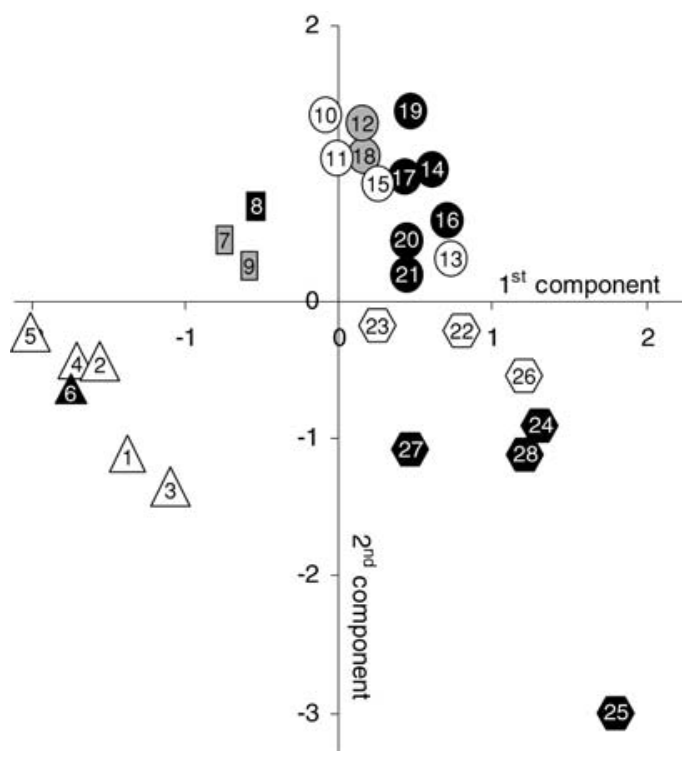

Fig. 2 Principal component analysis of variation at leaf morphological traits of 28 Quercus populations from Switzerland. Factor scores of the first (x-axis) and second (y-axis) component. Numbers of populations as in Table 1; shadings and symbols as in Fig. 1

Table 2 Average genetic diversity $\mathrm{H}_{\mathrm{e}}$ of Quercus populations from Switzerland belonging to different species and different cpDNA-haplotypes. Abbreviations as in Table 1. Values with different letters $(\mathrm{a}, \mathrm{b})$ are significantly different $(P<0.05)$ from each other

\begin{tabular}{llll}
\hline & & $\mathrm{H}_{\mathrm{e}}$ & \\
\hline Species & Q. robur & 0.241 & $\mathrm{a}$ \\
& Mixed Q. rob./Q. pet. & 0.256 & $\mathrm{a}$ \\
& Q. petraea & 0.249 & $\mathrm{a}$ \\
Haplotypes & Q. pubescens & 0.215 & $\mathrm{~b}$ \\
& "Eastern", & 0.239 & $\mathrm{a}$ \\
& "Western" & 0.234 & $\mathrm{a}$ \\
\hline
\end{tabular}

cant impact of the species status on allele frequencies was observed for eight out of 75 alleles at the $5 \%$ level $\left(\right.$ AAP-A ${ }_{2}$, GOT-B 1, GOT-B 3, MNR-A 6 , MNR-A 7 , 6PGDH- $\mathrm{B}_{3}$, PGI- $\mathrm{B}_{5}$ and PGM- $\mathrm{A}_{3}$ ), for another six alleles at the $1 \%$ level $\left(\mathrm{ACO}-\mathrm{A}_{3}, \mathrm{IDH}-\mathrm{A}_{2}, \mathrm{IDH}_{-} \mathrm{B}_{3}, \mathrm{IDH}-\mathrm{B}_{4}, 6-\right.$

Table 3 Average genetic distances $d_{0}$ (Gregorius 1984) at 17 isozyme gene loci between pairs of Quercus populations from Switzerland belonging to the same or different species and haplotypes. Only populations dominated by a single species ( 25 populations)
PGDH- $\mathrm{B}_{5}$ and PGM- $\mathrm{A}_{2}$ ), and for one allele at the $0.1 \%$ level $\left(\mathrm{MNR}-\mathrm{A}_{3}\right)$. The frequency of at least one allele was significantly influenced by the species status of the populations at nine out of the 17 investigated isozyme gene loci.

The hierarchical partitioning of genetic variation according to Nei (1973) was also confined to the 23 populations dominated by a single species and a single haplotype. Most of the total variation was found within populations $(92.8 \%)$. The remaining component of genetic differentiation was mainly among species $(5.0 \%)$. The differentiation among haplotypes within species was extremely low $(0.3 \%)$, and only $1.9 \%$ of the total variation was due to differentiation among populations within haplotypes and species. The proportion of the total diversity due to differentiation among populations $\left(\mathrm{F}_{\mathrm{ST}}=\mathrm{G}_{\mathrm{ST}}\right)$ for single species was $1.2 \%$ for $Q$. petraea, $2.7 \%$ for $Q$. pubescens and $1.9 \%$ for $Q$. robur.

Average genetic distances, $\mathrm{d}_{0}$, between populations of the same species were significantly lower than average distances between populations belonging to different species (Table 3 ). Average genetic distances between $Q$. robur populations and either $Q$. petraea or $Q$. pubescens populations were significantly higher than the average distance between $Q$. petraea and $Q$. pubescens populations. However, all genetic distances between species were only moderate, and no alleles were observed which unambiguously allowed us to differentiate among species. The small differences between the average genetic distances between populations of the same haplotype (both "eastern" and "western") and the average distances between populations with differing haplotypes were statistically not significant (Table 3 ).

The UPGMA-cluster diagram based on genetic distances, $\mathrm{d}_{0}$, (Fig. 3) confirmed the conclusion from the hierarchical partitioning of genetic variation and the computation of genetic distance measures. Patterns of genetic differentiation among populations were primarily influenced by the species status of populations without a major impact of the two investigated cpDNA haplotypes.

or a single haplotype (24 populations) were considered. Values with different letters $(\mathrm{a}-\mathrm{e})$ are significantly different $(P<0.05)$ from each other

\begin{tabular}{|c|c|c|c|c|}
\hline \multicolumn{2}{|c|}{ Population comparison } & \multirow{2}{*}{$\frac{\text { Number of population pairs }}{15}$} & \multicolumn{2}{|c|}{ Average genetic distance } \\
\hline Within species & Q. robur & & 0.057 & $\mathrm{a}$ \\
\hline & Q. petraea & 66 & 0.056 & $\mathrm{a}$ \\
\hline & Q. pubescens & 21 & 0.069 & $\mathrm{~b}$ \\
\hline \multirow[t]{3}{*}{ Between species } & Q. petraea $-Q$. pubescens & 84 & 0.089 & $\mathrm{c}$ \\
\hline & Q. robur $-Q$. petraea & 72 & 0.135 & $\mathrm{~d}$ \\
\hline & $Q$. robur $-Q$. pubescens & 42 & 0.148 & $\mathrm{e}$ \\
\hline \multirow[t]{2}{*}{ Within haplotype } & "Eastern” & 66 & 0.102 & $\mathrm{a}$ \\
\hline & "Western" & 66 & 0.093 & $\mathrm{a}$ \\
\hline Between haplotypes & "Eastern" - "Western" & 144 & 0.102 & $\mathrm{a}$ \\
\hline
\end{tabular}



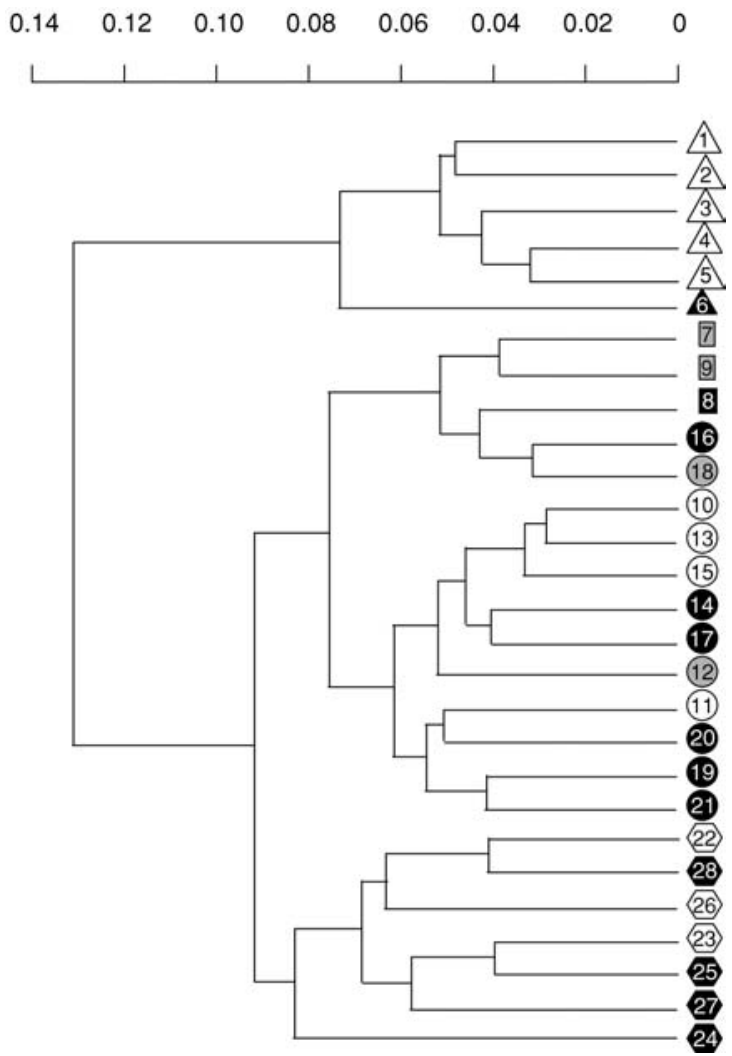

Fig. 3 Cluster diagram (UPGMA based on genetic distances $d_{0}$ ) illustrating genetic differentiation among 28 Quercus populations from Switzerland at 17 isozyme gene loci. Numbers of populations as in Table 1. Shadings and symbols as in Fig. 1

\section{Discussion}

Several observations point towards the significance of hybridization for patterns of genetic variation in $Q$. robur, $Q$. petraea and $Q$. pubescens. The species share identical cpDNA haplotypes, and the haplotype distribution within a region is similar for the three species (Petit et al. 1997; Dumolin-Lapègue et al. 1999). Differentiation among the species at nuclear gene loci is low. Complete differentiation between $Q$. robur and $Q$. petraea has neither been observed at isozyme gene loci nor at RAPD-markers (Bodénès et al. 1997). However, populations composed of different species can be distinguished by characteristic allelic structures at nuclear microsatellite loci (Muir et al. 2000). Non-overlapping ranges of allele frequencies for $Q$. petraea and $Q$. robur populations have also been observed at particular isozyme gene loci (e.g. IDH-B, PGM-A: Zanetto et al. 1994; Hertel and Degen 2000; Finkeldey 2001a) confirming that the observed morphological differentiation coincides with genetic differentiation between the species. An unambiguous distinction between $Q$. petraea and $Q$. pubescens based on leaf morphological characteristics is hardly possible in the Swiss Alps and areas north of the Alps (Aas 1998; Mátyás 1999; Müller 1999). Both species form a complex with many intermediate forms. Genetic structures of $Q$. petraea and $Q$. pubescens populations at isozyme gene loci were very similar to each other, while $Q$. robur populations were more strongly differentiated both at leaf morphological traits (Fig. 2) and at isozyme gene markers (Table 3, Fig. 3). All investigated populations harbor considerable genetic variation (Table 1), but the average expected heterozygosity of $Q$. pubescens populations was slightly, but significantly, lower than those of both other species (Table 2).

There is strong evidence for a different recolonization history of oak populations with different cpDNA haplotypes in Switzerland. The European-wide distribution of cpDNA haplotypes strongly suggests glacial refugia of Swiss populations, with "western" cpDNA haplotypes in central or southern Italy. Putative refugia of Swiss populations, with "eastern" cpDNA haplotypes are more doubtful. These populations may have survived the last glaciation on the Balkan peninsula and/or in presumably small refugia in southern France or north-western Italy (Mátyás and Sperisen 2001).

Long periods of wide spatial separation are likely to result in genetic differentiation not only at maternally inherited chloroplast genes but also at biparentally inherited nuclear genes (Avise 1994). Thus, populations with a different recolonization history are expected to be differentiated from each other both at maternal and biparental marker genes, resulting in an association between variation patterns of gene markers with different modes of inheritance. We failed to detect any association between variation patterns at maternally inherited cpDNA haplotypes and variation patterns at biparentally inherited isozyme gene loci. Glacial survival in different refugial areas and postglacial migration history are the crucial factors for determining the variation patterns of cpDNA of oaks in Switzerland, but had no obvious impact on biparentally inherited genes such as isozyme loci.

Strong differentiation among Quercus populations at maternally inherited markers, but weaker differentiation at biparentally inherited genes, has not only been observed in Switzerland but throughout the European continent (e.g. Kremer and Zanetto 1997; Petit et al. 2002). Restricted gene flow through seeds, but extensive gene flow through pollen, are likely to be the main causes of the contrasting patterns of genetic differentiation of maternal and biparental gene markers in oaks (Ennos 1994). Gene flow among populations through pollen is likely to be the principal evolutionary factor homogenizing the genetic structures of populations with a different recolonization history at nuclear genes, which were putatively genetically differentiated from each other before they came into reproductive contact again. This seems to hold at least for the spatial and temporal scale of this study, which covers a total area of approximately $40,000 \mathrm{~km}^{2}$ and a time period of roughly 8,000 to 11,000 years since the start of immigration of oaks to this area (Burga and Perret 1998). The weak, but significant, differentiation among species at isozyme gene loci points towards evolutionary significant but restricted gene flow among species. 
The investigation of maternally inherited gene markers, such as the cpDNA of most angiosperms, has considerably improved our understanding of the phylogeography of plants (Schaal et al. 1998). However, patterns of genetic differentiation at isozyme gene loci among Quercus populations in Switzerland are not primarily shaped by their glacial and postglacial history, but by species status and by extensive gene flow through pollen both within and among species. Thus, insights into the phylogeography of oaks in Switzerland gained through the investigation of maternally inherited markers do not provide a clue for the explanation of patterns of genetic differentiation at biparentally inherited loci. Different results were obtained in studies covering larger parts of the distribution area of the widely occurring Fagaceae: Significant regional differentiation among widely separated populations covering several glacial refugia and recently occupied areas was observed at isozyme gene loci in beech (Fagus sylvatica), another widely distributed anemogamous and barochorous tree of the Fagaceae family (Comps et al. 2001). Stronger differentiation between populations with different cpDNA-haplotypes and, thus, different recolonization history, was also observed at isozyme loci in European-wide studies on oaks, mainly Q. petraea (Le Corre et al. 1997; Kremer et al. 2002). Thus, the lack of differentiation among oak populations with a different recolonization history is at least partially explained by the limited size of the investigated area. However, comparable results may be expected in regional studies on other widely distributed plants with efficient means of pollen dispersal but restricted migration through seeds.

Acknowledgements The authors are grateful to Fabienne Bourquin and Annie Diarra for laboratory assistance, and to Patrick Bonfils and Marcus Ulber for their help during selection of the investigated populations and field work. Critical comments of Felix Gugerli, Rolf Holderegger and an anonymous reviewer helped to improve earlier drafts of the manuscript. Research was financially supported by the Swiss Agency for the Environment, Forests and Landscape (Bundesamt für Umwelt, Wald und Landschaft; $B U W A L)$. The encouragement of Markus Bolliger (BUWAL) is gratefully acknowledged.

\section{References}

Aas G (1998) Morphologische und ökologische Variation mitteleuropäischer Quercus-Arten: ein Beitrag zum Verständnis der Biodiversität. IHW, Eching, Germany

Avise JC (1994) Molecular markers, natural history and evolution. Chapman and Hall, New York London

Bacilieri R, Ducousso A, Petit RJ, Kremer A (1996) Mating system and asymmetric hybridization in a mixed stand of European oaks. Evolution 50:900-908

Backhaus K, Erichson B, Plinke W, Weiber R (2000) Multivariate Analysemethoden: eine anwendungsorientierte Einführung. Springer, Berlin Heidelberg New York

Berg EE, Hamrick JL (1997) Quantification of genetic diversity at allozyme loci. Can J For Res 27:415-424

Bodénès C, Joandet S, Laigret F, Kremer A (1997) Detection of genomic regions differentiating two closely related oak species Quercus petraea (Matt.) Liebl. and Quercus robur L. Heredity 78:433-444
Braeunig M, Fitch R (1998) WinSTAT: das Statistik-Programm. Springer, Berlin Heidelberg New York

Brändli UB (1996) Die häufigsten Waldbäume der Schweiz. Ergebnisse aus dem Landesforstinventar 1983-1985: Verbreitung, Standort und Häufigkeit von 30 Baumarten. Ber Eidgenöss Forschanst Wald Schnee Landsch 342. Swiss Federal Research Inst, WSL, Birmensdorf, Switzerland

Burga CA, Perret R (1998) Vegetation und Klima der Schweiz seit dem jüngeren Eiszeitalter. Ott, Thun, Switzerland

Comps B, Gömöry D, Letouzey J, Thiébaut B, Petit RJ (2001) Diverging trends between heterozygosity and allelic richness during postglacial colonization in the European beech. Genetics 157:389-397

Dumolin S, Demesure B, Petit R (1995) Inheritance of chloroplast and mitochondrial genomes in pedunculate oak investigated with an efficient PCR method. Theor Appl Genet 91:1253-1256

Dumolin-Lapègue S, Demesure B, Fineschi S, Le Corre V, Petit R (1997) Phylogeographic structure of white oaks throughout the European continent. Genetics 146:1475-1487

Dumolin-Lapègue S, Kremer A, Petit RJ (1999) Are chloroplast and mitochondrial DNA variation species independent in oaks? Evolution 53:1406-1413

Dupouey JL, Badeau V (1993) Morphological variability of oaks [Quercus robur L. Quercus petraea (Matt.) Liebl. Quercus pubescens Willd.] in northeastern France: preliminary results. Ann Sci For 50 (Suppl 1):35s-40s

Ennos RA (1994) Estimating the relative rates of pollen and seed migration among plant populations. Heredity 72:250-259

Ferris C, Oliver RP, Davy AJ, Hewitt GM (1993) Native oak chloroplasts reveal an ancient divide across Europe. Mol Ecol 2:337-344

Finkeldey R (2001a) Genetic variation of oaks (Quercus spp.) in Switzerland. 1. Allelic diversity and differentiation at isozyme gene loci. For Genet 8:185-195

Finkeldey R (2001b) Genetic variation of oaks (Quercus spp.) in Switzerland. 2. Genetic structures in "pure" and "mixed" forests of pedunculate oak ( $Q$. robur L.) and sessile oak $[Q$. petraea (Matt.) Liebl.]. Silvae Genet 50:22-30

Gillet EM (1994) GSED. Genetic structures from electrophoresis data. Version 1.0. User's manual. Institute of Forest Genetics and Forest Tree Breeding, Göttingen, Germany

Gregorius H-R (1984) A unique genetic distance. Biometr Jour 26 $13-18$

Hertel H, Degen B (2000) Unterscheidung von Stiel- und Traubeneichen [Quercus robur L. und $Q$. petraea (Mattuschka) Liebl.] mit Hilfe von genetischen und morphologischen Merkmalen. For, Snow Landscape Res 75:169-183

Hewitt G (2000) The genetic legacy of the Quaternary ice ages. Nature 405:907-913

Huntley B, Birks HJB (1983) An atlas of past and present pollen maps for Europe: 0-13,000 years ago. Cambridge University Press, Cambridge

Kremer A, Zanetto A (1997) Geographical structure of gene diversity in Quercus petraea (Matt.) Liebl. II. Multilocus patterns of variation. Heredity 78:476-489

Kremer A, Kleinschmit J, Cottrell J, Cundall EP, Deans JD, Ducousso A, König AO, Lowe AJ, Munro RC, Petit RJ, Stephan BR (2002) Is there a correlation between chloroplastic and nuclear divergence, or what are the roles of history and selection on genetic diversity in European oaks? For Ecol Management 156:75-87

Le Corre V, Dumolin-Lapegue S, Kremer A (1997) Genetic variation at allozyme and RAPD loci in sessile oak Quercus petraea (Matt.) Liebl.: the role of history and geography. Mol Ecol 6:519-529

Mátyás G (1999) Rekonstruktion der nacheiszeitlichen Einwanderung der Eichen in der Schweiz anhand ihrer ChloroplastenDNA. Dissertation ETH No. 13386. Swiss Federal Institute of Technology, Zürich

Mátyás G, Sperisen C (2001) Chloroplast DNA polymorphisms provide evidence for postglacial recolonisation of oaks (Quercus spp.) across the Swiss Alps. Theor Appl Genet 102:12-20 
Müller B (1999) Variation und Hybridisierung von Quercus pubescens. Dissertation ETH No. 13025. Swiss Federal Institute of Technology, Zürich

McCauley DE (1995) The use of chloroplast DNA polymorphism in studies of gene flow in plants. Trends Ecol Evol 10:198-202

Muir G, Fleming CC, Schlötterer C (2000) Species status of hybridizing oaks. Nature 405:1016

Müller-Starck G, Zanetto A, Kremer A, Herzog S (1996) Inheritance of isoenzymes in sessile oak [Quercus petraea (Matt.) Liebl.] and offspring from interspecific crosses. For Genet 3: $1-12$

Nei M (1973) Analysis of gene diversity in subdivided populations. Proc Natl Acad Sci USA 70:3321-3323

Petit R, Pineau E, Demesure B, Bacilieri R, Ducousso A, Kremer A (1997) Chloroplast DNA footprints of postglacial recolonization by oaks. Proc Natl Acad Sci USA 94: 999610,001

Petit R, Brewer S, Bordács S, Burg K, Cheddadi R, Coart E, Cottrell J, Csaikl U, van Dam B, Deans JD, Espinel S, Fineschi S, Finkeldey R, Glaz I, Goicoechea PG, Jensen JS, König A, Lowe AJ, Madsen SF, Mátyás G, Munro RC, Popescu F, Slade D, Tabbener H, de Vries SGM, Ziegenhagen B, de Beaulieu J-L, Kremer A (2002) Identification of refugia and post-glacial colonisation routes of European white oaks based on chloroplast DNA and fossil pollen evidence. For Ecol Management 156:49-74

Prevosti A, Ocaña J, Alonso G (1975) Distances between populations of Drosophila subobscura, based on chromosome arrangement frequencies. Theor Appl Genet 45:231-245

Reboud X, Zeyl C (1994) Organelle inheritance in plants. Heredity $72: 132-140$

Schaal BA, Hayworth DA, Olsen KM, Rauscher JT, Smith WA (1998) Phylogenetic studies in plants: problems and prospects. Mol Ecol 7:465-474

Sneath PHA, Sokal RR (1973) Numerical taxonomy. Freeman, San Francisco

Sokal RR, Rohlf FJ (1995) Biometry: the principles and practice of statistics in biological research, 3rd edn. Freeman, New York

Swofford DL, Selander RB (1981) BIOSYS-1: a FORTRAN program for the comprehensive analysis of electrophoretic data in population genetics and systematics. J Hered 72:281-283

Zanetto A, Roussel G, Kremer A (1994) Geographic variation of inter-specific differentiation between Quercus robur L. and Quercus petraea (Matt.) Liebl. For Genet 1:111-123

Zanetto A, Kremer A, Müller-Starck G, Hattemer HH (1996) Inheritance of isozymes in pedunculate oak (Quercus robur L.). J Hered 87:364-370 